\section{DIARY}

British Dental Conference \&t

Exhibition 2013

Date: 25-27 April 2013

Venue: ExCeL London

www.bda.org/conference

ADI 2013 Congress

Date: 1-3 May 2013

Venue: Manchester Central

Convention Complex

www.adi.org.uk/congress2013

Preparation for the Diploma in Implant Dentistry

Date: 10 May 2013

Venue: The Royal College

of Surgeons of Edinburgh

www.rcsed.ac.uk/education/

courses-and-events/coursedetails.

aspx?diaryld $=1118$

Dental Sedation Teachers

Group Symposium

Date: 14 May 2013

Venue: Millennium Stadium, Cardiff www.dstg.co.uk

Scottish Dental Show

Date: 16-17 May 2013

Venue: Hampden Park, Glasgow

www.scottishdentalshow.co.uk

A Multi Disciplinary Approach

to Dentofacial Orthopaedics

Date: 24 May 2013

Venue: Holiday Inn,

Welbeck Street, London

Telephone: Richard Dean,

01342824580

Premium education on digital dentistry: Sirona Imaging User Days

Date: 7 June 2013

Telephone: 08450715040

Email:info@sironadental.co.uk

British Society of Gerodontology and National Oral Health

Promotion Group Combined

Study Day 2013

Date: 14 June 2013

Venue: Burlington Macdonald Hotel,

Birmingham

www.nohpg.org

www.gerodontology.com

Association for Dental

Education in Europe meeting

Date: 28-31 August 2013

Venue: Wolfson Centre,

University of Birmingham

www.birmingham.ac.uk/adee2013

\title{
STUDENTS ADVISE SJÖGREN'S SUFFERERS
}

Dental students from Plymouth University Peninsula Schools of Medicine and Dentistry have worked with local people with Sjögren's syndrome to create an oral health advice leaflet which is to be made available via the British Sjögren's Syndrome Association.

The students have worked with the local group as part of their programme of special study units, interacting with a wide variety

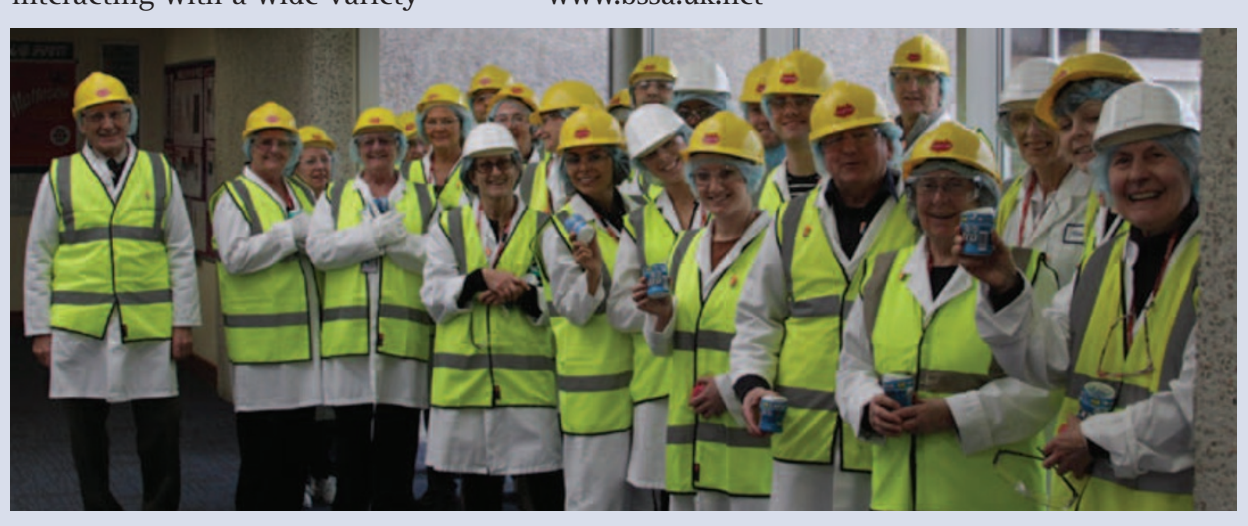

\section{GOVERNMENT LAUNCHES} SALT STRATEGY

Alongside continuing headlines on the sugar content in food and in our diets, the Government has launched a major drive to help reduce the amount of salt we eat by a quarter.

Research figures from the Department of Health (DH) show that 53\% of the public rarely or never consider salt content when buying food, despite 86\% of people knowing that too much salt is bad for their health, causing high blood pressure, which could lead to heart disease and stroke.

Public Health Minister Anna Soubry has launched a new 'Salt Strategy' which outlines how the DH will help people reduce their daily intake from an average of $8.1 \mathrm{~g}$ a day towards the $6 \mathrm{~g}$ a day goal. It will revise 2012 salt targets for industry; push the catering and take-away sector to do more; ask companies to help people choose lower salt options; and get more companies across the food industry to sign up to salt reduction.

Ninety companies have already signed up to make salt reduction a priority.

\section{SUBMIT YOUR VIEWS ON ORAL HEALTH TARGETS}

The Platform for Better Oral Health in Europe is seeking views on their draft European targets in a consultation that runs until December this year. The targets are intended to serve as a basis to benchmark EU Member States' progress towards increased prevention of oral diseases and improved oral health in Europe by 2020.

The targets specifically address the issues of improving collection systems, preventive policies, and education and awareness. The platform hopes to involve stakeholders and professional associations across member states in helping to further refine and focus the proposed targets. www.oralhealthplatform.eu/ proposed-2020-targets-forbetter-oral-health 